\title{
Recombinant GroES in combination with CpG oligodeoxynucleotides protects mice against Mycobacterium avium infection
}

\author{
LANFRANCO FATTORINI, ROBERTA CRETI, ROBERTO NISINI, ROBERTA PIETROBONO, \\ YUMING FAN, ANNARITA STRINGARO*, GIUSEPPE ARANCIA*, \\ OTTAVIANO SERLUPI-CRESCENZI, ELISABETTA IONA and GRAZIELLA OREFICI
}

Laboratory of Bacteriology and Medical Mycology and * Laboratory of Ultrastructures, Istituto Superiore di Sanità, Viale Regina Elena 299, 00161 Rome, Italy

\begin{abstract}
The groES gene of Mycobacterium avium strain 485 was cloned and expressed in Escherichia coli and the recombinant GroES protein was purified by affinity chromatography. The GroES preparation showed high purity by electrophoresis and immunoblotting. Immuno-electron microscopy showed that GroES was located both in the cytoplasm and on the surface of the mycobacterial cells and thus is readily available to interact with the host immune system. BALB/c mice were immunised intranasally with recombinant GroES, alone or in combination with a synthetic oligodeoxynucleotide containing unmethylated $\mathrm{CpG}$ motifs, and tested for protection against infection with $M$. avium. Neither GroES nor CpG alone provided any protection against subsequent challenge with $M$. avium, whereas a combination of the two significantly protected the lungs and spleen against colonisation by $M$. avium after intranasal challenge with a low dose of the organism. This indicates that intranasal administration of GroES and CpG oligodeoxynucleotides increases the resistance of $\mathrm{BALB} / \mathrm{c}$ mice to $\mathrm{M}$. avium infection.
\end{abstract}

\section{Introduction}

Organisms belonging to the Mycobacterium avium complex are environmental mycobacteria that can cause disseminated infections in AIDS patients and pulmonary disease in individuals without predisposing conditions [1]. M. avium infections are thought to occur by colonisation of the respiratory and gastrointestinal tracts [2,3], e.g., from aerosols generated by showers and from natural waters in which $M$. avium can reach concentrations of up to $1000 \mathrm{cfu} / \mathrm{ml}$ [4]. Cellular responses play a role in the development of immunity to $M$. avium infections but only a few antigens of the organism have been cloned and characterised. One of these is GroES, a $10-\mathrm{kDa}$ heatshock protein (HSP 10) which interacts functionally with GroEL (HSP 65) in protein folding and assembly $[5,6]$. M. tuberculosis GroES is known to be produced

Received 24 May 2002; revised version received 26 July 2002; accepted 31 July 2002.

Corresponding author: Dr G. Orefici (e-mail: gorefici@iss.it). extracellularly because it can be recovered from the conditioned medium of bacterial cultures $[7,8]$.

In man, GroES appears to be an immunodominant antigen as it induces antibodies and T-cell proliferation in patients with leprosy and tuberculosis [9]. However, much less is known about the potential role of GroES proteins as protective immunogens. For instance, intradermal immunisation of mice with recombinant $M$. leprae GroES, emulsified in Freund's incomplete adjuvant, has been shown to protect animals against multiplication of M. leprae [10]. Furthermore, mucosal immunisation with a recombinant Helicobacter pylori GroES-like protein and cholera toxin has been shown to protect mice against H. pylori infection [11].

In recent studies, synthetic oligodeoxynucleotides containing an unmethylated $\mathrm{CpG}$ dinucleotide flanked by two $5^{\prime}$-purines and two $3^{\prime}$-pyrimidines have been reported to be potent adjuvants for intranasally administered proteins $[12,13]$. CpG-containing sequences induce Th1-like responses and can be superior to cholera toxin in inducing immune responses [14]. 
However, no studies have been reported on the protective activity of mycobacterial proteins combined with $\mathrm{CpG}$ adjuvants. For this reason, the groES gene of M. avium was cloned and expressed in Escherichia coli and the recombinant GroES protein and a $\mathrm{CpG}$ oligodeoxynucleotide were investigated for their ability to protect mice against $M$. avium infection.

\section{Materials and methods}

\section{Micro-organism}

M. avium strain 485 was isolated from the blood of an AIDS patient [15]. Smooth transparent colonies, which are known to be associated with high virulence and resistance to antimicrobial agents, were used [1].

\section{Cloning of the M. avium groES gene}

M. avium cells were grown in Middlebrook $7 \mathrm{H} 9$ broth (Difco) at $37^{\circ} \mathrm{C}$, with agitation, to an optical density of 0.2 at $500 \mathrm{~nm}\left(\mathrm{OD}_{500}\right)$ and used for the preparation of chromosomal DNA [16]. A pair of degenerate primers corresponding to residues $8-14$ and $79-85$ of the $M$. tuberculosis GroES protein [17] were used to amplify a portion of the M. avium groES gene by PCR. The PCR product ( $234 \mathrm{bp}$ ) was sequenced on both strands by the dideoxy-chain termination method [18] to verify its specificity and was used as a probe in Southern hybridisation experiments [16]. When M. avium genomic DNA was digested with restriction endonuclease $P v u I I$ (New England Biolabs), a single positive signal at $c .800 \mathrm{bp}$ was obtained. Accordingly, $P v u \mathrm{II}$-restricted chromosomal DNA was cloned in the PvuII site of the phagemid Bluescript SK+ (Stratagene) and used to transform E. coli XLI competent cells (Stratagene). Recombinant plasmids harbouring the fragment of interest were identified by colony hybridisation with the 234-bp PCR product. One clone (pMAC1), containing a 817-bp insert, was sequenced on both strands.

\section{Production of the GroES recombinant protein}

To express the M. avium GroES protein in E. coli, the $M$. avium groES gene was amplified by PCR from the pMAC1 clone with Pyrococcus furiosus DNA polymerase (Stratagene) and inserted into pDS56 (forward primer 5'-GGGAAAGGATCCGTGGCGAAGGTGAA CATC-3' and reverse primer 5'-GGGAAAAAGCTTA CTTGGAGACGACAGC-3') and pQE60 (forward primer 5'-GGGAAACCATGGCGAAGGTGAACATCA-3' and reverse primer $5^{\prime}$-GGGAAAAGATCTCTTGGAG ACGACAGCCAG-3') vectors (Qiagen) to place the $6 \times$ histidine (His)-affinity tag at the amino $(\mathrm{N})$ terminal or at the carboxy $(\mathrm{C})$-terminal of the fusion protein, respectively. Recombinant plasmids were sequenced (forward primer 5'-CGGATAACAATTTCA CACAG-3' and reverse primer 5'-GTTCTGAGGTCAT TACTGG-3') to verify that the correct open reading frame had been maintained and used to transform $E$. coli M15 (pREP4) competent cells for the isopropyl- $\beta$ D-thiogalactoside (IPTG) inducible expression of the His-tagged GroES proteins [19]. E. coli M15 cells were grown in the presence of ampicillin $100 \mathrm{mg} / \mathrm{L}$ and kanamycin $50 \mathrm{mg} / \mathrm{L}$. When the culture reached an $\mathrm{OD}_{600}$ of 0.7 , IPTG was added to a final concentration of $1.5 \mathrm{mM}$ to induce expression. E. coli M15 cells transformed with the pQE56 plasmid encoding the mouse (His)-tagged dihydrofolate reductase protein were used as a control. To follow the time-course of the protein production, 1-ml samples of E. coli M15 cultures were collected at various times by centrifugation and boiled for $3 \mathrm{~min}$ in loading buffer. A 20- $\mu$ l volume of each sample was subjected to SDS-PAGE and proteins were visualised by staining with Coomassie Blue (see below).

For GroES purification, E. coli M15 cells expressing the recombinant GroES protein were collected after incubation for $5 \mathrm{~h}$ with IPTG. The bacteria were disrupted by adding lysozyme and by repeated freezethaw cycles. After centrifugation to remove cell debris, the supernates were applied to a nickel-nitrilotriacetic acid (Ni-NTA) affinity chromatography column [19], which has a remarkable selectivity for proteins containing 6-histidine residues when charged with nickel ions. All purification steps were performed in native (non-denaturing) conditions and recombinant proteins were eluted with $500 \mathrm{mM}$ imidazole. Recombinant GroES protein preparations were analysed for endotoxin content by the Limulus amoebocyte lysate assay (Sigma) and were shown to contain $<0.1$ endotoxin units $/ \mathrm{ml}$.

\section{Preparation of anti-GroES serum}

New Zealand White rabbits (Charles River) were inoculated intravenously on days $0,7,14$ and 21 with a mixture containing $0.5 \mathrm{mg}$ of recombinant GroES in $1 \mathrm{ml}$ of phosphate-buffered saline (PBS, $\mathrm{pH} \mathrm{7)}$; the mixture was emulsified with $1 \mathrm{ml}$ of incomplete Freund's adjuvant (Difco) and $2 \mathrm{ml}$ of Tween $802 \%$ $\mathrm{v} / \mathrm{v}$. Animals were exsanguinated on day 28; the blood was allowed to clot and serum was stored in aliquots at $-80^{\circ} \mathrm{C}$. The antibody titre of the polyclonal anti-GroES serum was determined by ELISA as described previously [20], with minor modifications.

\section{SDS-PAGE and immunoblotting}

M. avium sonicate was prepared by treatment of mycobacteria at $4^{\circ} \mathrm{C}$ for $25 \mathrm{~min}$ (1-min cycles with 1min cooling intervals) with a VCX $400 \mathrm{~W}$ ultrasonic disintegrator (Sonics \& Materials, Danbury, CT, USA). Recombinant GroES and $M$. avium sonicate were subjected to SDS-PAGE in separating gels containing acrylamide (BioRad) $15 \% \mathrm{w} / \mathrm{v}$ and the proteins were visualised by staining with Coomassie Blue as described previously [20]. Separated proteins were 
transferred on to nitrocellulose in a Mini-Trans-Blot module (BioRad). Nitrocellulose strips were soaked for $1 \mathrm{~h}$ at $37^{\circ} \mathrm{C}$ in Tris- $\mathrm{HCl}$ buffered saline $(\mathrm{NaCl} 0.9 \%$ $\mathrm{w} / \mathrm{v}, 0.01 \mathrm{M}$ Tris, $\mathrm{pH} 7.4$ ) containing bovine serum albumin 3\% w/v (Tris-BSA) and incubated for $2 \mathrm{~h}$ at room temperature with the anti-GroES serum diluted 1 in 2000 in Tris-BSA containing Tween $200.05 \% \mathrm{v} / \mathrm{v}$ (Tris-BSA-Tween). After washing in Tween $200.05 \%$ $\mathrm{v} / \mathrm{v}$ in saline, the strips were incubated for $1 \mathrm{~h}$ at room temperature with goat anti-rabbit IgG alkaline phosphatase conjugate diluted 1 in 5000 with Tris-BSATween and washed in Tween $200.05 \% \mathrm{v} / \mathrm{v}$ in saline. Binding of the enzyme-labelled antibodies was detected with the AP colour development reagent and fast red (BioRad).

\section{Cellular distribution of GroES}

M. avium cells were grown either to late logarithmic phase (4 days) or to stationary phase (7 days) and then either heat-shocked at $48^{\circ} \mathrm{C}$ for $1 \mathrm{~h}$ or not. Immunoelectron microscopic observations were made with antiGroES serum (diluted 1 in 10) and gold-conjugated protein A (5 nm diameter, diluted 1 in 50). Both unfixed, unembedded bacteria and chemically fixed, resin-embedded cells were examined. In the first case, cells were harvested by centrifugation, incubated with the anti-GroES serum or the pre-immune rabbit serum, washed in PBS (pH 7.4) twice, labelled with protein Agold and observed without any further treatment. This method ensured the best antigenic preservation but allowed labelling of only the surface components. To explore whether an internal labelling could occur, ultrathin sections were prepared. Bacteria were harvested by centrifugation, washed twice in PBS and suspended in the same buffer containing paraformaldehyde $0.5 \%$ $\mathrm{w} / \mathrm{v}$ and glutaraldehyde $1 \% \mathrm{w} / \mathrm{v}$. Cells were embedded in Lowicryl HM20 resin (Taab) and labelled by the post-embedding method [21].

\section{Protection experiments in mice}

Phosphorothioate CpG [12] was synthesised (MMedica, Florence, Italy) based on a previously published sequence (TGACTGTGAACGTTCGAGATGA) [22]. Male BALB/c mice were immunised intranasally on day 0,14 and 28 with $40 \mu \mathrm{l}(20 \mu \mathrm{l}$ per nostril) of PBS containing $10 \mu \mathrm{g}$ of recombinant GroES, $10 \mu \mathrm{g}$ CpG, $10 \mu \mathrm{g}$ GroES $+10 \mu \mathrm{g}$ CpG, or with PBS alone. Animals were sedated by intraperitoneal administration of $10 \mu \mathrm{l} / \mathrm{g}$ body weight of a solution containing ketamine $5 \mathrm{mg} / \mathrm{ml}$ and xylazine $0.3 \mathrm{mg} / \mathrm{ml}$. On day 42 , mice were challenged intranasally with $10^{3}$ or $2 \times 10^{4}$ cfu of $M$. avium. On day 84, viable bacterial numbers in the spleens and lungs were determined. Organs were collected aseptically and ground in homogenisers in Middlebrook $7 \mathrm{H} 9$ broth (6 ml final volume). Four $0.5-\mathrm{ml}$ volumes, either undiluted or diluted 10-fold with distilled water containing Tween $800.05 \% \mathrm{v} / \mathrm{v}$, were plated on to
Middlebrook 7H10 agar (Difco). After incubation for 10-14 days in a humidified atmosphere containing $\mathrm{CO}_{2} 5 \%$, colonies were counted and the numbers of cfu per whole organ were determined.

\section{Statistical analysis}

The statistical significance of the data was determined by Student's $t$ test; $\mathrm{p}$ values $<0.05$ were considered significant.

\section{Results}

\section{Production of GroES recombinant protein}

Sequence analysis of the 817-bp PvuII/PvuII fragment in clone pMAC1 displayed the entire groES gene (nucleotides 212-511) plus the first 72 codons of the cpn60.1 gene (nucleotides 602-817), a groEL homologue (Fig. 1). The predicted amino acid sequence of the groES gene gave a 100 -amino acid protein with a deduced molecular mass of $10.7 \mathrm{kDa}$. The 817-bp fragment is deposited in the EMBL GenBank under accession no. AF079544.

After IPTG induction of E. coli M15 cells transformed with the groES gene, the C-terminally His-tagged GroES protein appeared to be expressed efficiently (Fig. 2). On the other hand, only a slight expression of the N-terminally His-tagged GroES protein was observed (data not shown). A 100-ml volume of E. coli M15 culture grown to an $\mathrm{OD}_{600}$ of 0.7 before induction yielded c. $1.5 \mathrm{mg}$ of purified GroES protein.

\section{Antigenic properties and cellular distribution of GroES}

The immune serum produced in rabbits immunised with the recombinant GroES showed an ELISA titre of 256000. The recombinant GroES of M. avium showed a high degree of purity, as assessed by the presence of a single major band and the lack of extra bands by SDS-PAGE and immunoblotting (Fig. $3 a$ and b, lane 2 ); the specificity of the immune serum was proved by the observation that whole-cell ultrasonicates gave only one band in immunoblotting (Fig. $3 \mathrm{a}$ and b, lane 1). Moreover, absorption of the serum with recombinant GroES completely removed this reaction (data not shown). These observations indicated that the recombinant GroES preparation represented a homogeneous protein suitable for further studies. The size of the recombinant GroES appeared to be slightly greater than that of native GroES because of the presence of six histidine residues in the recombinant protein.

It was observed by immuno-electron microscopy that expression of GroES was markedly enhanced after heat-shock treatment of the logarithmic phase M. avium cells. GroES was abundant on the surface of the intact bacteria, associated with capsular material (Fig. 4b), 


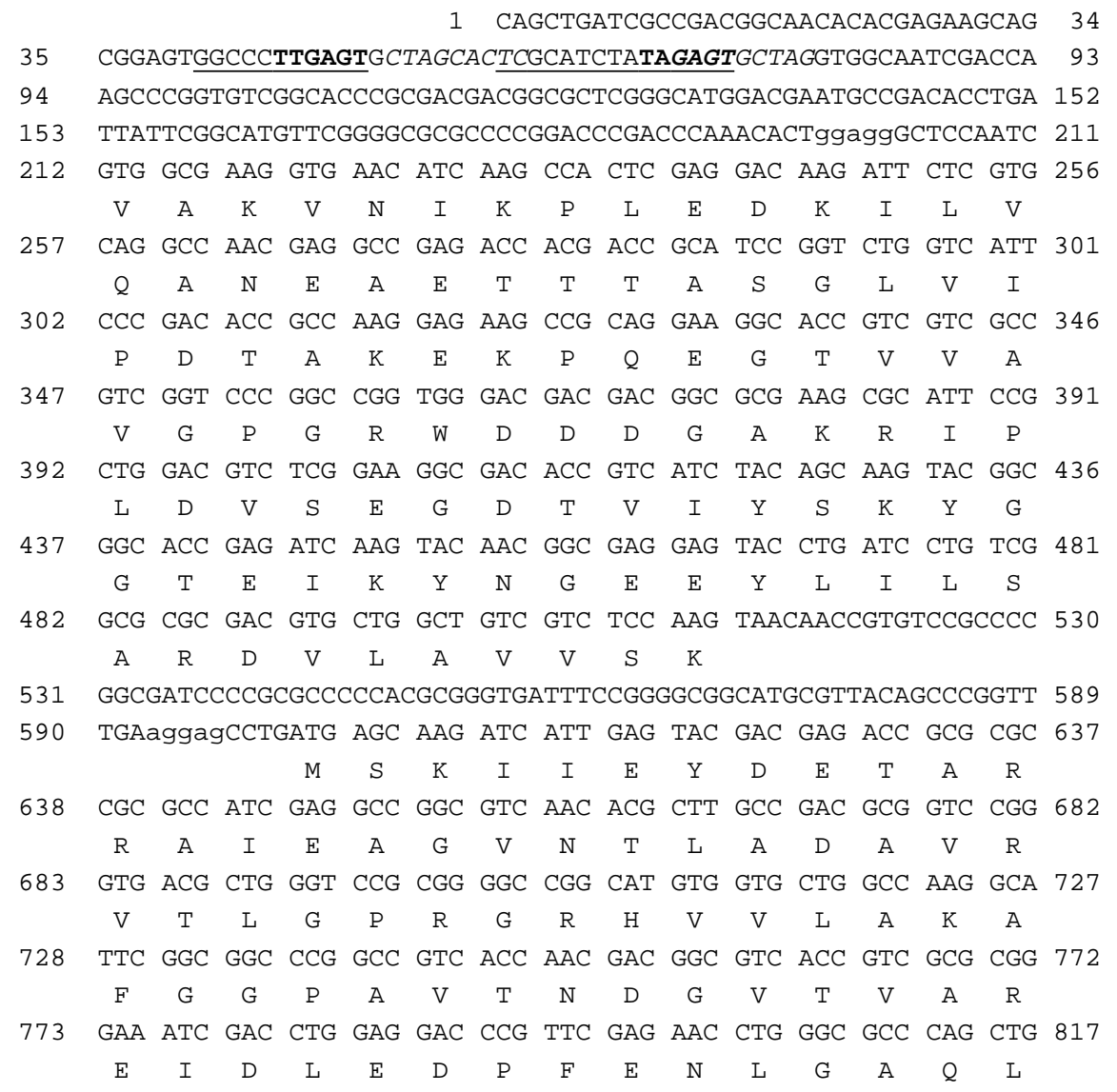

Fig. 1. Nucleotide sequence of the 817-bp PvuII/PvuII fragment (pMAC1). In the upstream region (nucleotides 1-211), the $\sigma^{70}$ RNA polymerase -35 and -10 promoter sequences (nucleotides $46-51$ and $69-74$ ) are in bold type; the $\sigma^{32}$ RNA polymerase -35 and -10 specific sequences for HSPs (nucleotides $41-51$ and 60-74) are underlined; the CIRCE (controlling inverted repeats of chaperone expression) sequence (nucleotides 53-61 and 71-79), consisting of a 9-bp inverted repeat separated by a 9-bp region unique to HPS-coding operons, is in italics [25, 26]; a Shine-Dalgarno sequence (nucleotides 198-202) is in lower case. The fragment includes the entire groES gene (nucleotides 212-511), a region containing a Shine-Dalgarno sequence (nucleotides 593597), and the first 72 codons (nucleotides $602-817$ ) of the cpn60.1 gene, a groEL homologue [23, 24]. The deduced amino acid sequences of the GroES protein and of part of the Cpn60.1 protein are shown below the corresponding nucleotide sequence.

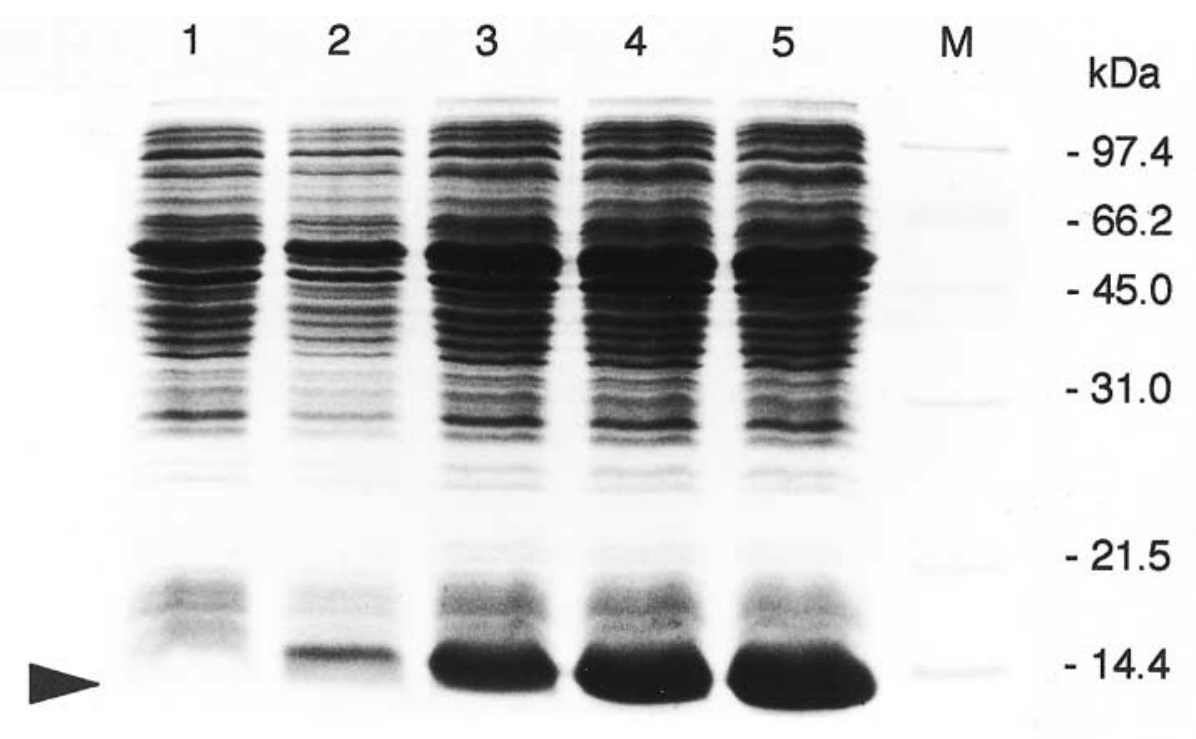

Fig. 2. Whole-cell protein profiles (SDS-PAGE) of E. coli M15 expressing (His) 6 -GroES protein at the time of IPTG addition (lane 1) and at 1, 2, 3 and $4 \mathrm{~h}$ (lanes $\mathbf{2}-\mathbf{5}$, respectively) after induction. M, molecular mass markers; the arrow indicates the GroES band. 
a

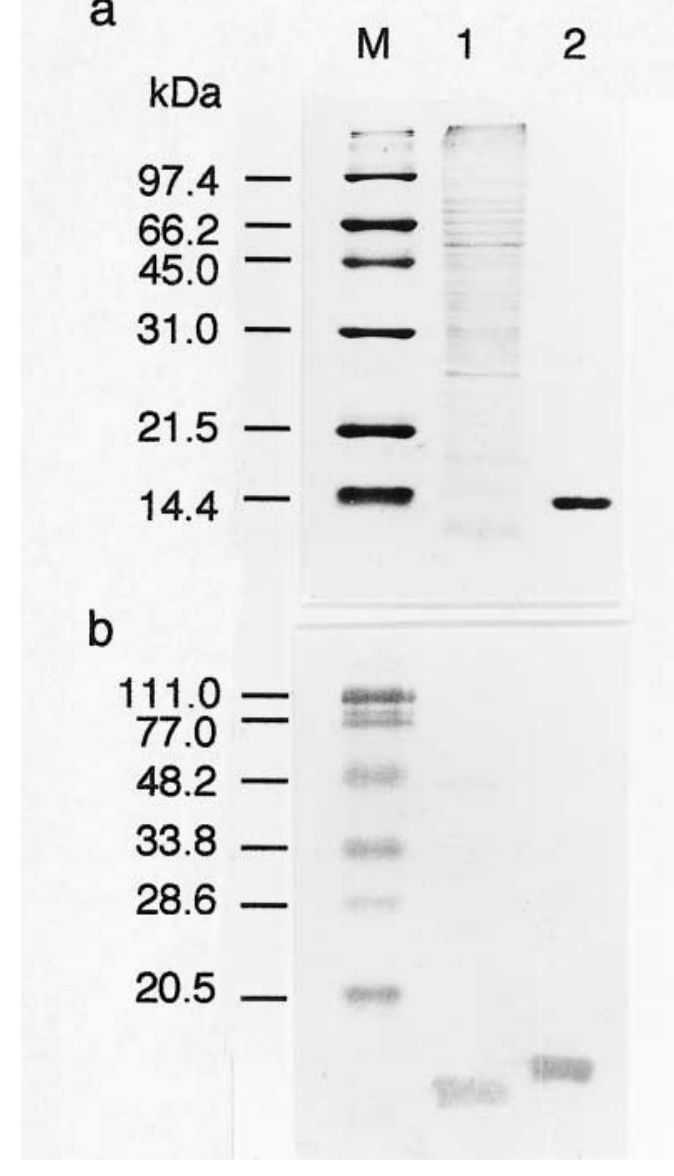

Fig. 3. (a) SDS-PAGE of sonicate of $M$. avium ( $5 \mu \mathrm{g}$ protein, lane 1) and the recombinant His-tagged GroES protein $(0.5 \mu \mathrm{g}$, lane 2). M, molecular mass markers. (b) Immunoblot, with the rabbit anti-GroES serum, of the sonicate of $M$. avium (1 $\mu \mathrm{g}$ protein, lane 1) and the recombinant His-tagged GroES protein $(0.1 \mu \mathrm{g}$, lane 2$)$. M, molecular mass markers.

and both in the cytoplasm and on the surface of sectioned cells (Fig. 4d). No relevant labelling was detected when cells were not heat-shocked (Fig. 4a and c), or when they reached the stationary phase (data not shown). No labelling was seen with cells treated with the pre-immune rabbit serum.

\section{Protection experiments in mice}

In preliminary experiments, BALB/c mice immunised subcutaneously with recombinant GroES plus incomplete Freund's adjuvant were not protected against infection after intraperitoneal challenge with $10^{5} \mathrm{cfu}$ of $M$. avium (data not shown). On the basis of this observation, and considering that the nasal mucosa is a probable entry point of $M$. avium into its host, the use of a mucosal adjuvant and a mucosal (intranasal) route of immunisation was investigated for protection of mice against intranasal challenge with $M$. avium.

When mice were challenged intranasally with $2 \times$ $10^{4} \mathrm{cfu}, M$. avium was recovered on day 1 in the lungs $\left(1.6 \mathrm{SD} 0.2 \times 10^{3} \mathrm{cfu}\right)$ but not in the spleen. The organism multiplied efficiently in both organs, as determined by the increase in cfu in non-immunised control mice by day 42 after challenge (Fig. 5a). At this time, mice immunised with GroES plus $\mathrm{CpG}$ showed significantly fewer organisms in the spleen when compared with non-immunised controls, unlike mice immunised with GroES or $\mathrm{CpG}$ alone. Under these experimental conditions, the lungs were not protected against the challenge dose.

To mimic more natural conditions of infection, a lower challenge dose $\left(10^{3} \mathrm{cfu}\right)$ was then administered by the nasal route. $M$. avium was recovered on day 1 in the lungs (1.2 SD $\left.0.2 \times 10^{2} \mathrm{cfu}\right)$ but not in the spleens. Again, the organism had multiplied both in the lungs and spleens of the control group by day 42 of the infection (Fig. 5b), although to a lower extent than in mice challenged with $2 \times 10^{4}$ cfu. However, while GroES or $\mathrm{CpG}$ alone did not induce any protection, significantly lower numbers of $M$. avium were observed both in the lungs and spleens of mice immunised with GroES plus $\mathrm{CpG}$, in comparison with control, GroES and $\mathrm{CpG}$ groups. No animal died during the course of the experiment.

\section{Discussion}

$M$. avium infects the mucosal surfaces of the respiratory and gastrointestinal tracts. Thus, development of mucosal vaccines against this organism is desirable and intranasal administration of a combined vaccine containing the recombinant GroES with a $\mathrm{CpG}$ adjuvant was tested for its ability to confer resistance to intranasal infection with $M$. avium on mice.

Sequence analysis of a DNA fragment containing the groES gene showed that $M$. avium, like other mycobacteria $[23,24]$, has a groESL operon. The fragment contained the groES gene and a part of the cpn60.1 gene, a groEL homologue. The operon is preceded by sequences for conventional and HSPspecific promoters and by a controlling inverted repeat (CIRCE) for chaperone expression [25, 26]. M. avium GroES showed $97 \%, 92 \%$ and $88 \%$ amino acid identity with the GroES of M. tuberculosis, M. bovis and $M$. leprae, respectively, with only one residue (D 53) unique to $M$. avium (data not shown).

The recombinant GroES preparation showed a high degree of purity, as demonstrated by the presence of a single major band by SDS-PAGE and immunoblotting. The specificity of the immune serum and its suitability for use in immunolocalisation studies were demonstrated by the observation that whole-cell ultrasonicates produced one major band in immunoblotting. The band (native GroES) showed a mol. wt slightly lower than that of recombinant GroES, in accordance with the observation that histidine-tagged proteins run more slowly than the equivalent, untagged proteins [27]. 


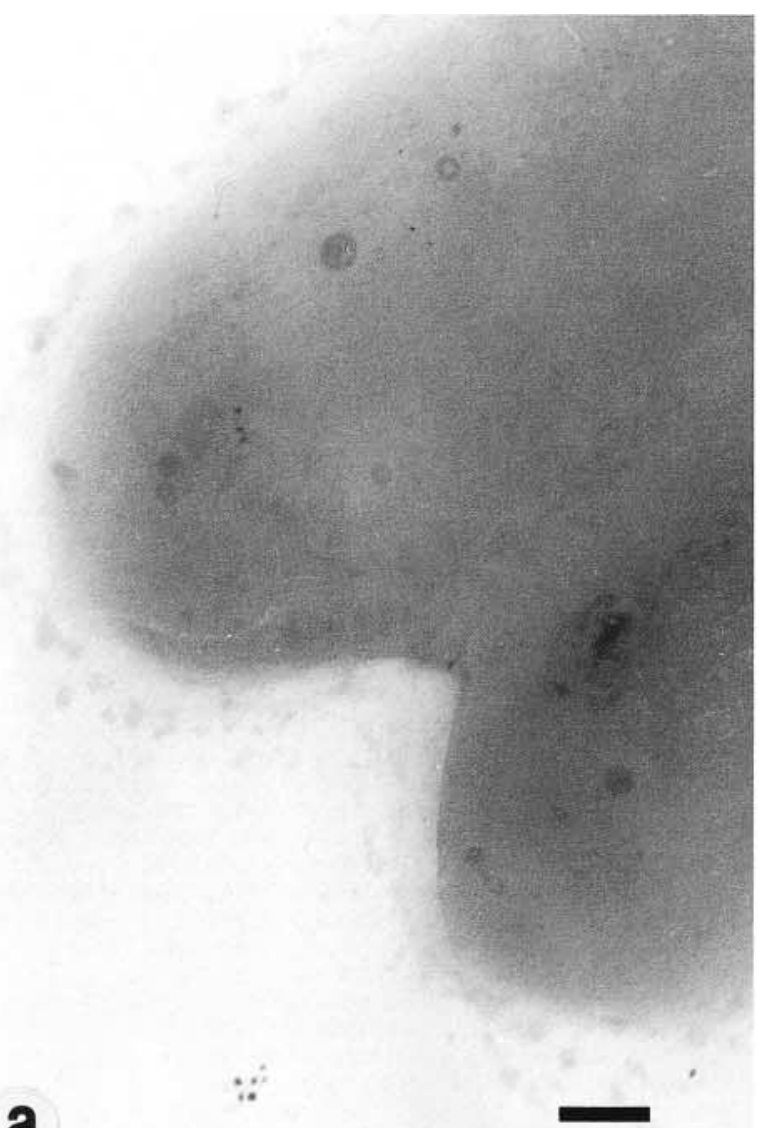

a

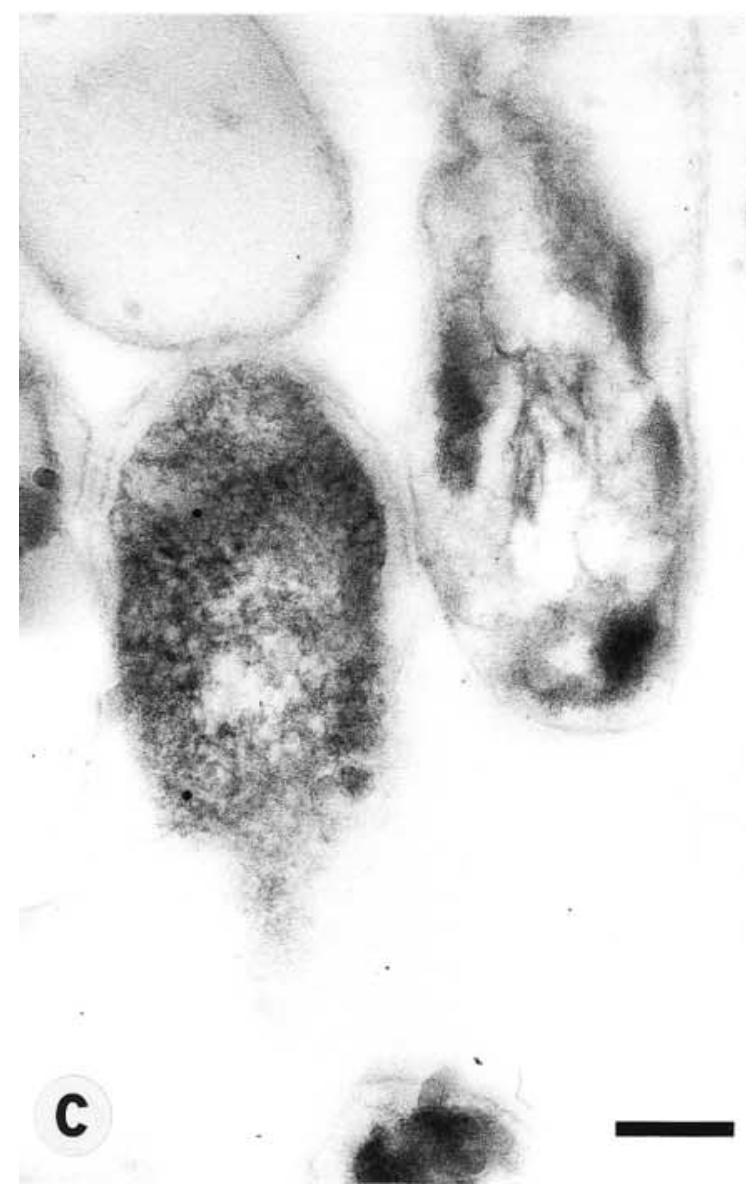

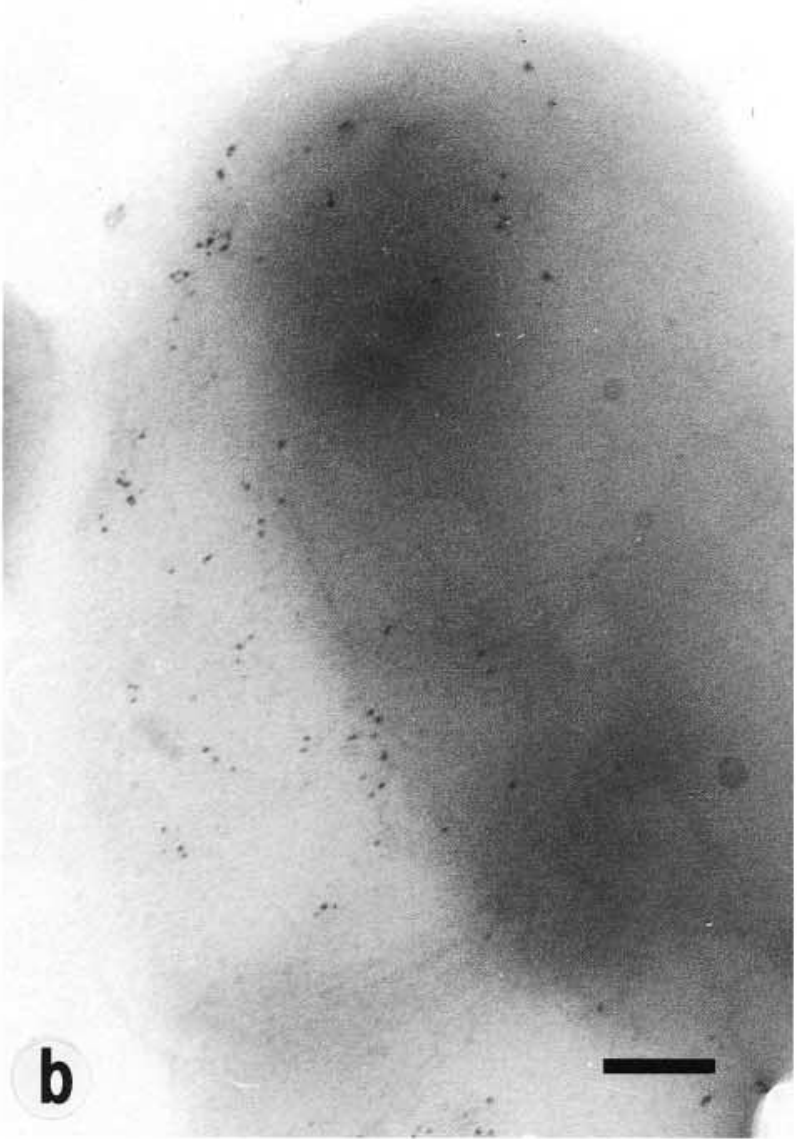

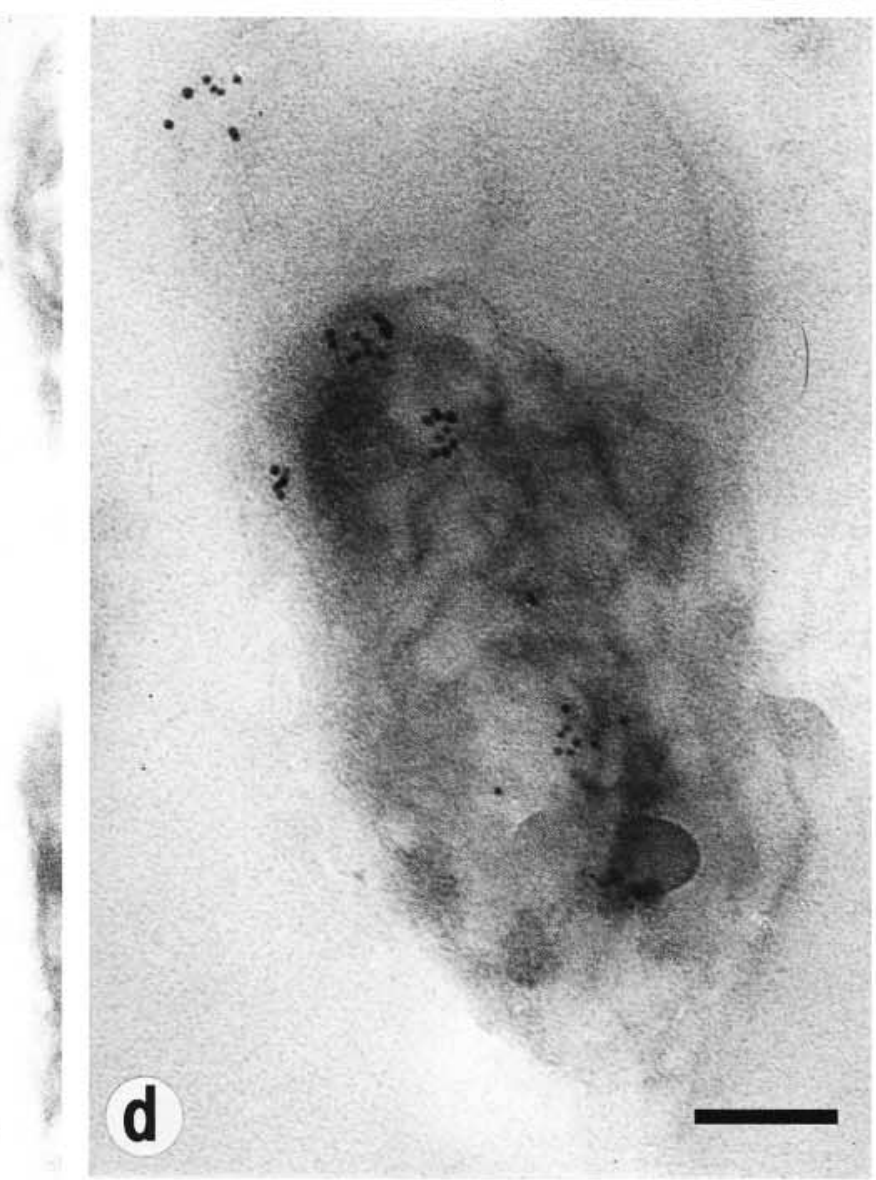

Fig. 4. Electron micrographs showing immunolocalisation of GroES. (a) Cells of M. avium grown at $37^{\circ} \mathrm{C}$. (b) Cells of $M$. avium after heat shock at $48^{\circ} \mathrm{C}$. (c) Ultra-thin sections of $M$. avium grown at $37^{\circ} \mathrm{C}$. (d) Ultra-thin sections of $M$. avium after heat-shock at $48^{\circ} \mathrm{C}$. Bars, $100 \mathrm{~nm}$. Gold particles measure $5 \mathrm{~nm}$ in diameter. 

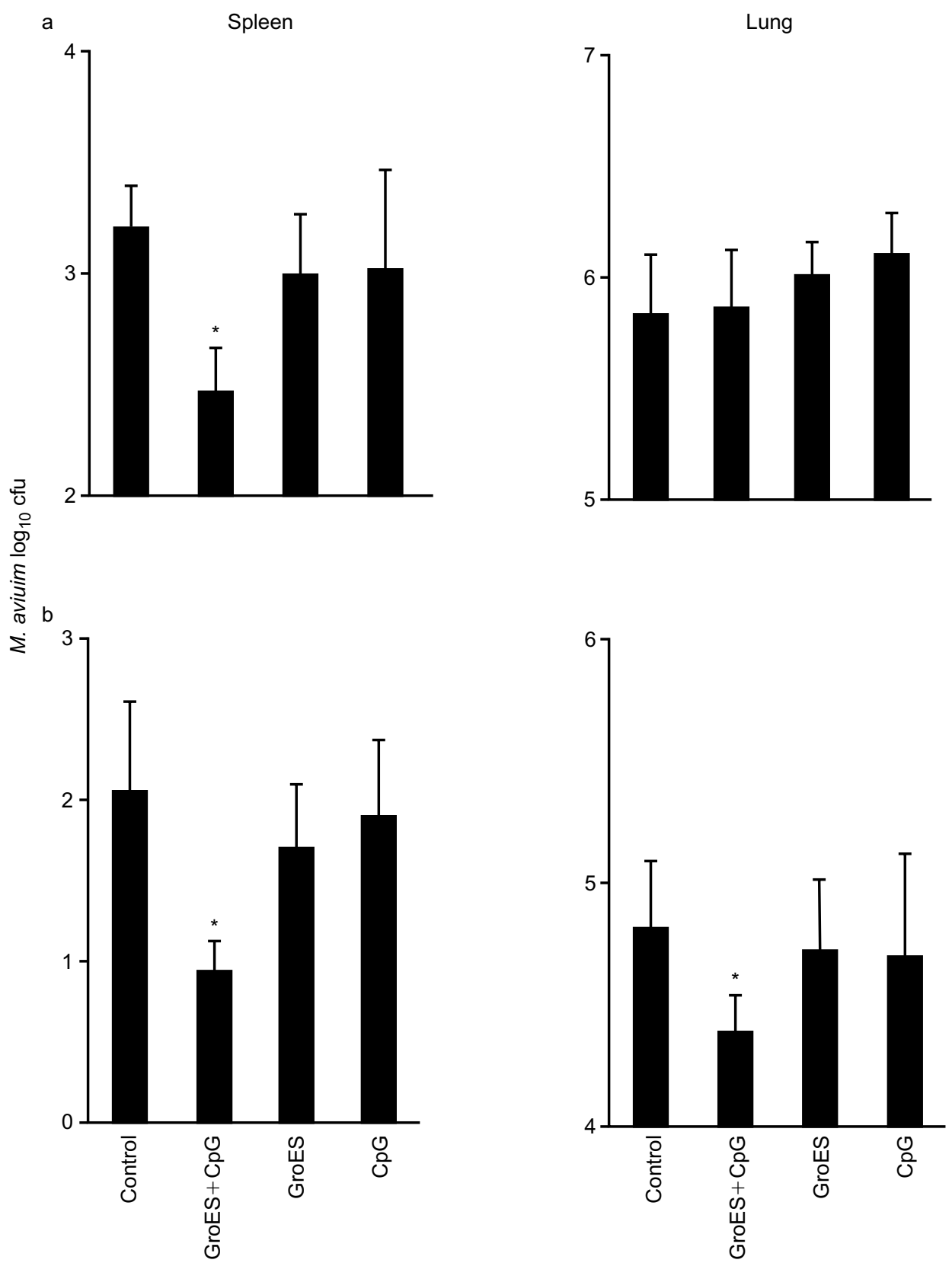

Fig. 5. Protection provided by recombinant GroES in combination with $\mathrm{CpG}$ oligodeoxynucleotides. Mice were immunised intranasally with $10 \mu \mathrm{g}$ GroES $+10 \mu \mathrm{g}$ CpG, $10 \mu \mathrm{g}$ GroES, $10 \mu \mathrm{g} \mathrm{CpG}$, or PBS (control) and challenged intranasally with $2 \times 10^{4} \mathrm{cfu}$ of $M$. avium (a), or $10^{3} \mathrm{cfu}(\mathbf{b})$ on day 42 . The numbers of cfu in the lungs and spleens of immunised and control mice on day 84 are shown. Data represent the means of three experiments $(n=6$ mice per group in each experiment). Error bars represent SD. ${ }^{*} \mathrm{p}<0.05$ in comparison with control, GroES and $\mathrm{CpG}$ groups.

As HSPs are usually regarded as intracellular proteins involved in protein folding and assembly, in theory they should not be found outside the cells. Nevertheless, M. tuberculosis GroES was found extracellularly $[7,8]$ either as a result of leakage from dead cells or secretion by live bacteria [9]. M. avium cells not stressed by heat-shock treatment showed few GroES molecules when examined by immuno-electron microscopy. In contrast, after heat-shock, GroES was present intracellularly and on the bacterial surface and thus would be readily available for interaction with the host immune cells. Other intracellular HSPs such as GroEL and HSP70 are also surface-expressed proteins, possi- bly functioning as adhesins and having a direct activating effect on various host cell populations [28].

The potential for cross-reactivity with mammalian proteins was thought to preclude a role for HSPs as vaccine candidates. However, immunisation of mice with GroES and GroES-like proteins protected animals against $M$. leprae [10] and H. pylori infections [11], respectively. Furthermore, DNA vaccines encoding the groEL gene induced very strong antituberculous activity in mice [29]. DNA vaccines are known to derive their immunogenic potential from the adjuvant action of sequences containing $\mathrm{CpG}$ motifs [30]. To 
date, most of the work with $\mathrm{CpG}$ as adjuvant has been performed with parenteral administration to mice [13] and non-human primates [31]. Intraperitoneal administration of $\mathrm{CpG}$ oligodeoxynucleotides protects mice against $M$. tuberculosis by inducing a Th1 response [32]. However, several studies have shown that intranasal delivery, with $\mathrm{CpG}$ oligodeoxynucleotides as adjuvants, results in strong systemic and mucosal immune responses to co-administered antigens, including hepatitis B surface antigen [14] and influenza virus [33]. Intranasal administration of $\mathrm{CpG}$ and interleukin12 also improves the efficacy of BCG vaccination in mice challenged with M. tuberculosis [34].

In agreement with these observations, the present study showed that BALB/c mice immunised intranasally with recombinant GroES protein with the addition of a $\mathrm{CpG}$ adjuvant acquired a significantly increased resistance to infection with $M$. avium after intranasal challenge. Protection was related to the mycobacterial burden from the challenge dose. When mice were challenged with a relatively high dose, the lungs were not protected by either GroES alone or GroES plus CpG. This dose gave rise to counts of $c .1600 \mathrm{cfu}$ per lung on day 1. Nevertheless, when a lower challenge dose $\left(10^{3} \mathrm{cfu}\right)$ was used, perhaps better resembling environmental conditions of infection [4], both lungs and spleen were significantly protected against $M$. avium. The latter dose gave rise to a count of $c .120 \mathrm{cfu}$ per lung on day 1, i.e., a mycobacterial burden which is expected to be partially contained in the lung by the emerging immune response [35].

One of the primary routes of infection by $M$. avium is the intranasal route. Our observation that intranasal administration of a single mycobacterial protein and a $\mathrm{CpG}$ adjuvant protects mice against mycobacterial infection by the same route suggests that other recombinant mycobacterial proteins should be investigated.

We are grateful to Pasqualina Crateri and Simona Recchia for their valuable technical assistance. This work was supported in part by the Italian AIDS Project, Istituto Superiore di Sanità, Ministero della Sanità, Grants 50D.5 and 50D.4.

\section{References}

1. Inderlied CB, Kemper CA, Bermudez LEM. The Mycobacterium avium complex. Clin Microbiol Rev 1993; 6: 266-310.

2. Horshburg CR. Epidemiology of Mycobacterium avium complex. In: Korvick JA, Benson CA (eds) Mycobacterium avium complex infection: progress in research and treatment. $M$. Dekker. 1996:1-22.

3. Middleton AM, Chadwick MV, Nicholson AG et al. The role of Mycobacterium avium complex fibronectin attachment protein in adherence to the human respiratory mucosa. Mol Microbiol 2000; 38: 381-391.

4. von Reyn CF, Waddel RD, Eaton $\mathrm{T}$ et al. Isolation of Mycobacterium avium complex from water in the United States, Finland, Zaire and Kenya. J Clin Microbiol 1993; 31: 3227-3230.

5. Georgopoulos C, Welch WJ. Role of the major heat shock proteins as molecular chaperones. Annu Rev Cell Biol 1993; 9: 601-634.
6. Cobb AJ, Frothingham R. The GroES antigens of Mycobacterium avium and Mycobacterium paratuberculosis. Vet Microbiol 1999; 67: 31-35.

7. Verbon A, Kuijper S, Jansen HM, Speelman P, Kolk AH. Antigens in culture supernatant of Mycobacterium tuberculosis: epitopes defined by monoclonal and human antibodies. $J$ Gen Microbiol 1990; 136: 955-964.

8. Orme IM, Miller ES, Roberts $\mathrm{AD}$ et al. $\mathrm{T}$ lymphocytes mediating protection and cellular cytolysis during the course of Mycobacterium tuberculosis infection. Evidence for different kinetics and recognition of a wide spectrum of protein antigens. J Immunol 1992; 148: 189-196.

9. Coates ARM. Immunological aspects of chaperonins. In: Ellis RJ (ed) The chaperonins. Academic Press. 1996: 267-296.

10. Gelber RH, Mehra V, Bloom B et al. Vaccination with pure Mycobacterium leprae proteins inhibits $M$. leprae multiplication in mouse footpads. Infect Immun 1994; 10: 4250-4255.

11. Ferrero RL, Thiberge JM, Kansau I, Wuscher N, Huerre M, Labigne A. The GroES homolog of Helicobacter pylori confers protective immunity against mucosal infection in mice. Proc Natl Acad Sci USA 1995; 92: 6499-6503.

12. Scheule RK. The role of $\mathrm{CpG}$ motifs in immunostimulation and gene therapy. Adv Drug Deliv Rev 2000; 44: 119-134.

13. McCluskie MJ, Davis HL. Oral, intrarectal and intranasal immunizations using $\mathrm{CpG}$ and non- $\mathrm{ppG}$ oligodeoxynucleotides as adjuvants. Vaccine 2001; 19: 413-422.

14. McCluskie MJ, Davis HL. CpG DNA is a potent enhancer of systemic and mucosal immune responses against hepatitis B surface antigen with intranasal administration to mice. $J$ Immunol 1998; 161: 4463-4466.

15. Fattorini L, Xiao Y, Ausiello CM et al. Late acquisition of hyporesponsiveness to lipopolysaccharide by Mycobacterium avium-infected human macrophages in producing tumor necrosis factor-alpha but not interleukin-1 beta and $-6 . J$ Infect Dis 1996; 173: 1030-1034.

16. Ausubel FM, Brent R, Kingston RE et al. Current protocols in molecular biology. New York, John Wiley \& Sons. 1995.

17. Mande SC, Mehra V, Bloom BR, Hol WGJ. Structure of the heat shock protein chaperonin-10 of M. leprae. Science 1996; 271: 203-207.

18. Sanger F, Nicklen S. Coulson AR. DNA sequencing with chain-terminating inhibitors. Proc Natl Acad Sci USA 1977; 74: 5463-5467.

19. Qiagen. The Qiaexpressionist, 3rd edn. Hilden, Germany, Qiagen. 1997.

20. Wagner B, Fattorini L, Wagner $\mathrm{M}$ et al. Antigenic properties and immunoelectron microscopic localization of Mycobacterium fortuitum beta-lactamase. Antimicrob Agents Chemother 1995; 39: 739-745.

21. Molinari A, Calcabrini A, Meschini S et al. Detection of Pglycoprotein in the Golgi apparatus of drug-untreated human melanoma cells. Int J Cancer 1998; 75: 885-893.

22. von Hunolstein $\mathrm{C}$, Mariotti S, Teloni $\mathrm{R}$ et al. The adjuvant effect of synthetic oligodeoxynucleotide containing $\mathrm{CpG}$ motif converts the anti-Haemophilus influenzae type b glycoconjugates into efficient anti-polysaccharide and anti-carrier polyvalent vaccines. Vaccine 2001; 19: 3058-3066.

23. Kong TH, Coates ARM, Butcher PD, Hickman CJ, Shinnick TM. M. tuberculosis expresses two chaperonin-60 homologs. Proc Natl Acad Sci USA 1993; 90: 2608-2612.

24. Rinke de Wit TF, Bekelie S, Osland A et al. Mycobacteria contain two groEL genes: the second Mycobacterium leprae groEL gene is arranged in an operon with groES. Mol Microbiol 1992; 6: 1995-2007.

25. Zuber U, Schumann W. CIRCE, a novel heat shock element involved in regulation of heat shock operon dnaK of Bacillus subtilis. J Bacteriol 1994; 176: 1359-1363.

26. Hecker M, Schumann W, Volker U. Heat-shock and general stress response in Bacillus subtilis. Mol Microbiol 1996; 19: 417-428.

27. Schon U, Schumann W. Construction of His6-tagging vectors allowing single-step purification of GroES and other polypeptides produced in Bacillus subtilis. Gene 1994; 147: 91-94.

28. Lewthwaite J, Skinner A, Henderson B. Are molecular chaperones microbial virulence factors? Trends Microbiol 1998; 6: 426-428.

29. Lowrie DB, Tascon RE, Bonato VL et al. Therapy of tuberculosis in mice by DNA vaccination. Nature 1999; 400: 269-271. 
30. Tighe H, Corr M, Roman R, Raz E. Gene vaccination: plasmid DNA is more than just a blueprint. Immunol Today 1998; 19: 89-97.

31. Jones TR, Obaldia N, Gramzinski RA et al. Synthetic oligodeoxynucleotides containing $\mathrm{CpG}$ motifs enhance immunogenicity of a peptide malaria vaccine in Aotus monkeys. Vaccine 1999; 17: 3065-3071.

32. Juffermans NP, Leemans JC, Florquin $\mathrm{S}$ et al. CpG oligodeoxynucleotides enhance host defense during murine tuberculosis. Infect Immun 2000; 70: 147-152.

33. Moldoveanu Z, Love-Homan L, Huang WQ, Krieg AM. CpG
DNA, a novel immune enhancer for systemic and mucosal immunization with influenza virus. Vaccine 1998; 16: 1216 1224.

34. Freidag BL, Melton GB, Collins F et al. CpG oligodeoxynucleotides and interleukin-12 improve the efficacy of Mycobacterium bovis BCG vaccination in mice challenged with $M$. tuberculosis. Infect Immun 2000; 68: 2948-2953.

35. Kelly BP, Furney SK, Jessen MT, Orme IM. Low-dose aerosol infection model for testing drugs for efficacy against Mycobacterium tuberculosis. Antimicrob Agents Chemother 1996; 40: 2809-2812. 